\title{
MODE WACANA BAHASA KEKUASAAN
}

\author{
Enie Hendrajati*
}

\begin{abstract}
Abstrak
Manusia dilahirkan tidak terlepas dari kegiatan ekonomi, sosial, budaya, dan politik. Hal ini mengisyaratkan bahwa manusia bukan saja sebagai makhluk sosial, ekonomi, dan budaya, akan tetapi juga termasuk makhluk politik. Dengan dasar bahwa manusia adalah makhluk politik yang ekuivalen makhluk dengan naluri berkuasa maka perilaku sosial-politiknya akan terpancar dalam bahasa dan perilaku berbahasanya. Manusia dalam berkegiatan dengan siapa pun, tentang apa pun, kapan pun, dan dengan saluran apa pun cenderung tidak bisa netral dari hasrat dan naluri untuk mempengaruhi, menguasai, mempertahankan, dan atau memperluas tindakan lainnya.

Mode wacana menunjuk pada bagian yang diperankan oleh bahasa, hal yang diharapkan oleh para pelibat dari bahasa yang digunakan, mode retoriknya, apa yang diharapkan pelibat dari gaya bahasa yang digunakan, apakah gaya bahasa yang digunakan dapat digolongkan sebagai didaktik, membujuk, menjelaskan dan semacamnya.

Bahasa kekuasaan yang merupakan keniscayaan atau naluri kemanusiaan tampaknya bergerak dalam lingkup derajat antara; berkisar antara. Manusia dalam berbahasa dengan naluri "transaksi", bahkan "berduel" dapat dengan bebas bergerak antara yang sarkastis hingga yang eufemistis (substansinya tetap naluri menguasai, bertransaksi, bernegosiasi, dan duel) asalkan masih dalam standar deviasi tertentu, atau batas kenormalan dan kelaziman. Melebihi batas kenormalan berarti abnormal, tidak lazim, gila dan adu fisik.

Bahasa dan kekuasaan adalah dwitunggal. Dalam komunikasi kebahasaan akan selalu ada nuansa-nuansa saling dominasi, kekuasaan, pengaruh, autoritas.Mode wacana yang menyertainya dapat bercorak retorik-persuasif, baik yang tampak rasional-persuasif maupun yang bercorak retorik emosionalpersuasif, bahkan yang bercita rasa agresif-dogmatis.

Kenyataan bahwa bahasa dengan mode retorik seperti itulah yang mengundang alternatif paradigma-teoritis sehingga kajian dan analisis bahasa dan wacana tidak sekedar dari paradigma empirisme-positivisme, tetapi juga dari paradigma fenomenologi, bahkan dengan paradigma discursive-practice.
\end{abstract}

Kata kunci: mode wacana, kekuasaan, bahasa, fenomenologi, empirismepositivisme, discursive-practice.

Kebudayaan universal cenderung tidak terlepas dari hidup dan kehidupan manusia. Dimana pun dan kapan pun manusia dilahirkan tidak terlepas dari kegiatan ekonomi, sosial, budaya, dan politik. Hal ini mengisyaratkan bahwa manusia bukan saja sebagai makhluk sosial, ekonomi, dan budaya, akan tetapi juga termasuk makhluk politik. Sebagaimana kata yang lain, kata politik dapat dipahami dari beberapa macam definisi. Dan Nimmo dalam bukunya,

\footnotetext{
* Dosen pada Jurusan MKU FMIPA ITS.
}

jsh Jurnal Sosial Humaniora, Vo. 2, No. 1, Juni 2009 
“Komunikasi Politik: Komunikator, Pesan, dan Media," (1993:8) memaparkan bahwa politik: (1) adalah siapa memperoleh apa, kapan dan bagaimana; (2) adalah pembagian nilai-nilai oleh yang barwenang; (3) kekuasaan dan pemegang kekuasaan; (4)adalah pengaruh; (5) adalah tindakan yang diarahkan untuk mempertahankan atau memperluas tindakan lainnya, (6) adalah pembicaraan untuk mempertahankan pembicaraan.

Definisi politik tersebut bukan sekedar mengisyaratkan dan meneguhkan, akan tetapi memastikan bahwa manusia itu adalah makhluk politik. Artinya, manusia dalam berkegiatan dengan siapa pun, tentang apa pun, kapan pun, dan dengan saluran apa pun cenderung tidak bisa netral dari hasrat dan naluri untuk nmempengaruhi, menguasai, mempertahankan, dan atau memperluas tindakan lainnya. Pemahaman tentang politik semacam ini tidak saja berada dalam lingkup setting formal-institusional, seperti eksekutif, legeslatif, dan yudikatif, akan tetapi juga bisa dalam lingkup dan setting informal-noninstitusional, misalnya percakapan antara dua orang di jalan, di rumah, dengan teman atau bukan, pagi atau sore hari, tentang masalah apa pun.

Dengan dasar bahwa manusia adalah makhluk politik yang ekuivalen makhluk dengan naluri berkuasa maka pertanyaannya adalah bagaimana perilaku sosial-politiknya terpancar dalam bahasa dan berhubungan dengan perilaku berbahasa? Norman Fairclough (1992:43) memaparkan hubungan bahasa dan kekuasaan ke dalam dua posisi, yaitu:

1) kekuasaan dalam wacana atau power in discourse, dengan kongkretisasinya: (a) kekuasaan dalam wacana percakapan bersemuka atau power in face-to- face spoken discourse, (b) kekuasaan dalam wacana lintas kultural, atau power in cross-cultural discourse, (c) kekuasaan tersembunyi dalam wacana media massa, atau hidden power of the discourse of the mass media;

2) kekuasaan di luar wanaca atau power behind discourse, dengan paparan tentang kekuasaan negara kaitannya dengan bahasa nasional, bahasa 
standar, kekuasaan dan aksesnya ke dalam wacana, tipe-tipe wacana, dan semacamnya.

\section{Bahasa dan Kekuasaan}

Adakah bahasa kekuasaan itu? Jika ada, bagaimana menjelaskan adanya? Apakah terlalu gegabah jika dengan serta merta dikatakan bahwa bahasa kekuasaan itu adalah bahasa yang digunakan penguasa; singkatnya, bahasa penguasa? Apakah setiap penguasa selalu atau tidak selalu menggunakan bahasa kekuasaan? Siapakah sebenarnya penguasa itu? Apakah setiap diri manusia adalah penguasa sehingga bahasa kekuasaan itu pun ada pada setiap diri manusia?

Bahasa adalah cermin diri. Cermin pikiran, perasaan, kemauan, kapasitaskapasitas, sikap, pandangan hidup, dan sebagainya. Di dalam bahasa, semuanya itu tergambar, tercermin, terpancar. Bahasa mencerminkan struktur diri, citra diri, jati diri, baik diri sebagai aku - individual - maupun diri sebgai kita, kami, atau bangsa (kolektif). Bahasa adalah Anda; bahasa menunjukkan bangsa. Itulah kesimpulan yang populer, yang menguatkan tesis bahwa manusia dan bahasa tidak terpisah meskipun keduanya berbeda. Berkenaan dengan pandangan atau pemahaman tersebut, beberapa ahli pikir berikut ini memberikan penjelasan yang serupa.

Dedy dan Yosal (1994:82): "Bagaimana cara yang menjadi kebiasaan Anda berbahasa telah tertanam secara mendalam di alam bawah sadar Anda sehingga bahasa Anda mencerminkan struktur diri dan pandangan Anda.”

"Setiap pernyataan adalah tindakan "penciptaan makna", yaitu tindakan pembentukan diri serta pengungkapan jati diri dari sang pembicara" (Hikam, 1996:80). Selanjutnya Hikam, (dalam Yudi Latif, 1996:77) menegaskan: "Bahasa dan praktek kebahasaan tidak lagi dimengerti dalam konteks perspektif konvensional, yaitu sebagai alat dan medium netral yang dipakai untuk menjelaskan kenyataan sosial-politik. Namun, semakin disadari bahwa bahasa, di dalam dirinya, tampil sebagai representasi dari dan ruang bagi pagelaran (deployment) berbagai macam kuasa. Oleh karena itu, bahasa lantas dilihat pula 
sebagai salah satu ruang (space) tempat konflik-konflik berbagai kepentingan, kekuasaan, proses hegemoni dan hegemoni tandingan terjadi."

Mochtar Pabottinggi (dalam Yudi Latif, 1996:161): "bahasa Indonesia mewakili suatu kuasa tertentu; ia mewakili suatu iklim politik tertentu. Pemakaiaannya tidak bisa berarti lain dari konfirmasi atau penyesuaian diri pada kuasa atau iklim politik tersebut".

Pandangan beberapa ahli pikir tersebut di atas mengisyaratkan bahwa manusia dan bahasanya bukan semata-mata tidak terpisah, akan tetapi manusia sebagai subyek pengguna bahasa berperan sangat sentral dan dominan dalam penciptaan dan pengungkapan suatu makna dan maksud. Jika benar demikian, maka pemahaman dan konfirmasi terhadap makna kata, kalimat, atau wacana tidak bisa otonom atrau independen, lepas terpisah dari subyek. Tidak bisa semata-mata menggunakan ukuran logis-gramatikal.

Jika bahasa adalah Anda (bagaimana Anda adalah bagaimana bahasanya) maka apakah Anda berkuasa? Manusia normal cenderung selalu berada dalam proses interaksi sosial, yaitu hubungan antara dua atau lebih individu manusia, di mana kelakuan individu yang satu mempengaruhi, mengubah, atau memperbaiki kelakuan individu yang lain, atau sebaliknya (Gerungan, 1983:61).

Dalam semua antarhubungan kemanusiaan, baik di antara dua atau lebih dari dua manusia, terdapat suatu unsur kekuasaan sebagai unsur struktural. Selalu terjadilah semacam adu mengadu kekuasaan yang menghasilkan suatu keseimbangan, yang kadang-kadang bersifat stabil, kadang-kadang tidak stabil (Mayor Polak, 1979:103).

Arnold M. Rose mengajukan "hipotesis multi-pengaruh" untuk menggambarkan realitas sosial sebagai sebuah konflik (dalam Dedy dan Yosal, 1994:103). Beberapa asumsi teoritis itu memperjelas bahwa setiap manusia adalah berkuasa, meskipun cenderung tidak disadari. Faktor psikologi (egoismeindividual), sosial (interdependensi), dan psikososial (imitasi, sugesti, simpati, dan identifikasi) yang cenderung mendasarinya. 
Berdasarkan paparan tentang hubungan antara bahasa, manusia dan kekuasaan dapatlah ditarik suatu proposisi: jika bahasa (A) tidak terpisah dari manusia (B), sementara manusia (B) tidak terpisah dengan kekuasaan (C) maka kesimpulannya adalah bahasa (A) tidak terpisah dengan kekuasaan (C). Bahasa rumusnya: Jika $A=B$, sementara $B=C$, maka dengan sendirinya $A=C$.

\section{Mode Wacana Bahasa Kekuasaan}

M.A.K. Halliday (1992:16) membagi menjadi tiga pokok bahasan yang dapat digunakan untuk menafsirkan konteks, atau lingkungan terjadinya pertukaran makna, yaitu: (1) medan wacana, yang menunjuk pada hal yang sedang terjadi, pada watak tindakan sosial yang sedang berlangsung; apa sebenarnya yang disibukkan oleh para pelibat? (2) Pelibat wacana, yaitu orangorang yang terlibat, sifat para pelibat, kedudukan dan peranan mereka; (3) mode atau sarana wacana, menunjuk pada bagian yang diperankan oleh bahasa, hal yang diharapkan oleh para pelibat dari bahasa yang digunakan, mode retoriknya, apa yang diharapkan pelibat dari gaya bahasa yang digunakan, apakah gaya bahasa yang digunakan dapat digolongkan sebagai didaktik, membujuk, menjelaskan dan semacamnya.

Artikel ini membahas bahasa kekuasaan dari segi mode wacananya. Tidak membahas medan wacana dan pelibat wacana bahasa kekuasaan. Oleh karena bahasa dan kekuasaan berhubungan, sedangkan kekuasaan tidak terlepas dari politik maka sangat relevan jika pembahasan tentang mode wacana bahasa kekuasaan menyertakan bidang politik.

Dalam membicarakan masalah politik, David V.J. Bell mengkategorikan suatu pembicaraan sebagai pembicaraan politik menjadi tiga bagian, yaitu: (1) pembicaraan kekuasaan, (2) pembicaraan pengaruh, dan (3) pembicaraan autoritas ( Nimmo, 1993:75). Pembicaraan kekuasaan cenderung sarat dengan ancamanancaman, sangsi-sangsi, janji, dominasi karena pelibat wacana komunikasi merasa memiliki kemampuan dan kompetensi untuk merealisasikannya. Bahasa rumusnya: Jika Anda melakukan X, saya akan melakukan Y. Di sini X adalah sikap atau tindakan orang lain yang diharapkan oleh pembicara; $Y$ adalah maksud 
yang dinyatakan untuk memberikan lebih banyak (janji) atau lebih sedikit kenikmatan (ancaman atau sangsi) atas sesuatu apabila sikap atau tindakan yang diharapkan pembicara dilakukan.

Pembicaraan pengaruh terjadi cenderung tanpa ancaman, janji-janji, dan sangsi-sangsi. Alat tukar pembicaraan pengaruh adalah nasihat, permintaan, dorongan, dan peringatan. Pembicara yang akan mempengaruhi pendengar hanya dengan modal prestise atau reputasinya dapat memanipulasi persepsi atau pengharapan orang lain (pendengar) terhadap kemungkinan mendapatkan untung atau rugi. Bahasa rumusnya: Jika Anda melakukan X, Anda akan mendapatkan sesuatu mengalami Y.

Pembicaraan autoritas tidak menggunakan alat tukar sangsi-sangsi atau ancaman-ancaman, janji, dan syarat-syarat. Karena kewenangannya maka sah-sah saja, bahkan benar-benar saja. Faktor adat, kapasitas, kompetensi, kedudukan resmi merupakan faktor penentunya. Bahasa rumusnya: Lakukan X, jalankan X, atau sebaliknya. Jadi, lebih berbentuk perintah daripada bentuk bersyarat. Ketiga bentuk pembicaraan tersebut dalam praktik cenderung bersimbiosis.

Berdasar pada tiga model pembicaraan tersebut, bagaimana mode retorik/wacana bahasa kekuasaan? Meskipun dapat bercorak rasional-persuasif, akan tetapi mode wacana/retorik bahasa kekuasaan cenderung lebih bercorak emosional-persuasif. Rasional-persuasif berarti bahwa gaya dan bahasa yang digunakan rasional dan wajar dengan tujuan pembuktian kebenaran obyek dan persesuiaan/kesepakatan rasional. Dengan demikian, makna signifikan dan makna atau pengertian bersama dicapai melalui proses transaksi rasional (lebih bercorak argumentatif-persuasif).

Mode wacana atau retorik bahasa kekuasaan cenderung lebih bercorak emosional-persuasif. Maksudnya, gaya dan bahasa yang digunakan lebih memanfaatkan pendekatan dan aspek-aspek psikologis. Jadi, yang menjadi titik tuju adalah psikologi atau emosi subyek atau pelibat wacana. Makna signifikan dan makna atau pengertian bersama dicapai melalui proses transaksi emosionalpsikologis. Oleh karena itu, mode wacana yang dibangun dengan corak 
emosional-persuasif cenderung lebih menggayakan pesan atau makna (gaya bahasa).

Membuat kategorisasi dikhotomis antara dua model dan gaya retoris itu tidaklah mudah karena masalah rasional dan emosional adalah masalah obyektif dan subyektif. Berikut ini diberikan beberapa contoh kalimat yang umum dan populer, tetapi bernuansa bahasa penguasa.

1). Persuasi bercorak agresif-dogmatis.

a. Mereka adalah orang-orang Komunis.

b. Mereka adalah tidak bersih lingkungan

2). Persuasi yang menunjukkan derajat kekuatan persuasi.

c. Pameran rumah.

d. Pameran tempat tinggal.

3). Persuasi yang menunjukkan intensitas bahasa/makna (intensitas bobot sikap).

e. positif.......hamba hukum, pengatur lalu-lintas.

f. netral.......polisi

g. negatif.......oknom polisi.

Contoh (a) dan (b) berkategori agresif-dogmatis karena kata adalah (mendefinisikan) berarti atau berkesan akan membuat kategorisasi, kepastian (batas), identitas. Padahal daur kehidupan manusia akan bergerak dan terus berproses personalisasi. Dengan adalah berpotensi agresif-dogmatis dan politis.

Contoh kalimat (c) kata rumah lebih lemah daya persuasinya daripada kalimat (d) tempat tinggal. Dengan ungkapan atau pernyataan (d) berarti pembicara, secara semantis berpotensi mendominasi makna dan maksud komunikasi.

Dengan beberapa contoh tersebut kiranya dapat dikatakan bahwa setiap pernyataan atau bahasa yang kita gunakan cenderung bercorak persuasif, yaitu bernuansa bahasa kekuasaan, baik disadari atau tidak disadari, langsung atau tidak langsung. 


\section{Bahasa Kekuasaan: Antara Absolutisme dan Relativisme}

Bahasa kekuasaan dengan segala mode, corak, dan gayanya (sebagaimana dipaparkan di atas) merupakan konsekuensi atau akibat naluri manusia untuk "berkuasa". Berkuasa dalam pengertian struktural dan fungsional,

- dari yang bersifat sarkastis hingga yang bersifat eufemistis;

- dari yang bersifat eksplisit hingga yang bersifat implisit;

- dari yang bersifat emosional-persuasif hingga yang bersifat rasionalpersuasif;

- dari bersifat otoriter-totaliter hingga yang bersifat demokratis-anarkis;

- dari yang bersifat absolut hingga yang bersifat relatif.

Dengan dasar tersebut maka bahasa kekuasaan yang dalam artikel ini dinyatakan sebagai naluri kemanusiaan tampaknya bergerak dalam lingkup derajat antara atau berkisar antara. Meminjam istilah statistik, yaitu distribusi normal maka orang dalam berbahasa dengan naluri "transaksi", bahkan "duelnya" itu dapat dengan bebas bergerak antara yang sarkastis hingga yang eufemistis (substansinya tetap naluri menguasai, bertransaksi, bernegosiasi, dan duel) asalkan masih dalam standar deviasi tertentu, atau batas kenormalan dan kelaziman. Melebihi batas kenormalan berarti abnormal, tidak lazim, gila/adu fisik. Standar deviasi yang dimaksud, misalnya adalah pandangan hidup atau ideologi. Sekali lagi, bahasa kekuasaan adalah sesuatu yang naluriah, pasti, hanya keberadaannya cenderung "berderajat antara", seberapa tampak eksplisit atau nuansa-nuansa, pernik-pernik naluri kekuasaan itu dalam bahasa antara lain ditandai munculnya kata atau istilah seperti:

- toleransi, yaitu tidak ada pihak yang mengalah, masing-masing saling mempertahankan, tetapi kedua belah pihak saling menghormati sehingga tidak ada permusuhan;

- kompromi, yaitu kedua belah pihak bersedia mengalah untuk kemudian saling memberi dn menerima, take and give;

- rekonsiliasi, yaitu rujuk;

- genjatan senjata, yaitu menunda permusuhan; 
- arbitrase, yaitu menggunakan pihak ketiga untuk menyelesaikan masalah/konflik/duel.

\section{Paradigma Teoretis}

Tiga paradigma teoretis yang akan dipaparkan di sini, yaitu empirismepositivisme, fenomenologi, dan discurve pratice. Faham empirisme-positivisme memiliki kerangka pemahaman bahwa bahasa adalah hasil refleksi kategorikategori mental kognitif manusia. Segala pengalaman mental kognitifnya diekspresikan dalam bahasa tanpa perlu curiga terhadap adanya distorsi-distorsi, selama ia dinyatakan secara logis-gramatikal. Lambang atau kata-kata, kalimat, dan bahasa merupakan representasi langsung dari obyek atau pengalaman. Pandangannya terhadap bahasa sangat polos. Ia hanya melihat bahasa sebatas alat dan mereduksinya menjadi sekedar perkara gramatika. Akibatnya, terpisahlah antara subyek dengan obyek; berarti putus pulalah upaya untuk membongkar makna-makna subyektif dan kontekstual.

Faham fenomenologi berpandangan bahwa bahasa dan wacana justru diatur dan dihidupkan oleh pengucapan-pengucapan yang bertujuan. Setiap pernyataan adalah tindakan penciptaan makna, yakni tindakan pembentukan diri serta pengungkapan jati diri dari sang pembicara (Hikam, 1996:80). Subyeklah yang menciptakan makna sehingga menjadi realitas. Lambang bukan representasi langsung dari obyek; dengan kata lain, kata-kata atau lambang dalam wacana tidak memiliki makna intrinsik yang independen. Jadi, bahasa selalu subyektif atau intersubyektivitas. Dengan paradigma semacam ini maka analisis bahasa berarti analisis subyek atau makna-makna subyektif, termasuk motif-motif dasarnya. Pernyataan dan pengucapan tidak bisa diterima secara polos dan apa adanya, meskipun ia tampak logis-gramatikal. Makna subyektif harus ditelusuri dengan melampaui makna polos atau makna obyektifnya. Metodenya adalah interpretasi dan interaksi simbolis.

Faham discursive- practive. Berbeda dengan dua faham terdahulu, paham ini menganggap bahwa gramatika dan subyek tidak lagi sebagai titik tolak analisis. Ia lebih menekankan kepada konstelasi kekuatan apa yang ada dalam 
proses pembentukan dan reproduksi makna. Faham ini meyakini bahwa faktor hubungan kekuasaan adalah inheren dalam setiap wacana. Kuasa dianggap senantiasa berada dalam setiap proses wacana. Dengan pemahaman ini, bahasa dan wacana senantiasa terlibat dalam hubungan kekuasaan terutama dalam proses pembentukan subyek. Pendekatan ini unggul dalam kepekaannya terhadap kuasa yang dianggap senantiasa hadir dalam setiap wacana. Dengan demikian ada keterbukaan dalam mengkaji dua kutup yang berlawanan, yaitu posisi yang berkuasa dan posisi yang dikuasai, baik makna yang dengan sendirinya juga hadir. Bagaimanapun juga, kuasa, dalam dirinya juga senantiasa mengandaikan perlawanan.

\section{Kesimpulan}

Bahasa, manusia, dan kekuasaan tidak terpisah, dan saling berhubungan. Bahasa dibentuk manusia, dan dengan kekuasaannya manusia memanfaatkan bahasa, yang difahami tidak polos dan tidak netral untuk menggelar kekuasaannya. Dengan demikian bahasa dan kekuasaan adalah dua dalam satu (dwitunggal). Artinya, dalam komunikasi kebahasaan akan selalu ada nuansanuansa konflik, saling dominasi (akibat interdependensi), kekuasaan, pengaruh, autoritas, paling "apes" nuansa toleransi.

Mode wacana yang menyertai kenyataan bahasa seperti itu adalah corak retorik-persuasif, baik yang tampak rasional-persuasif maupun yang bercorak retorik emosional-persuasif, bahkan yang bercita rasa agresif-dogmatis.

Kenyataan bahasa dengan mode retorik seperti itulah yang mengundang alternatif paradigma-teoritis sehingga kajian dan analisis bahasa tidak sekedar dari paradigma empirisme-positivisme, tetapi juga dari paradigma fenomenologi, bahkan dengan paradigma discursive-practice. 


\section{Daftar Pustaka}

Fairclough, Norman. 1983. Language and Power. Singapore: Longman Singapore Publishers (Pte) Ltd.

Gerungan, W.A. 1983. Psychologi-Sosial Suatu Ringkasan. Jakarta: PT Eresco.

Hikam, Muhammad A.S. 1996. "Bahasa dan Politik: Penghampiran "Discursive Practice". H. 77. dalam Yudi Latif dan Idi Subandi Ibrahim (Ed). Bahasa dan Kekuasaan: Politik Wacana di Panggung Orde Baru.Bandung: Mizan.

Halliday, M.A.K. dan Ruqaiya Hasan.1992. Bahasa, Konteks, dan Teks: Aspekaspek Bahasa dalam Pandangan Semiotik Sosial. Penerjemahan Drs. Asruddin Baron Tou, MA dari Language,Context, and Text: Aspect of Language in a Social-Semiotic Perspection.

Malik, Dedy Djamaluddin dan Yosal Iriantara (Ed) 1994. Komunikasi Persuasif. Bandung: PT Remaja Rosdakarya.

Nimmo, Dan. 1993. Komunikasi Politik:Komunikator, Pesan, dan Media. Penerjemah Tjun Surjaman dari Political Commonication in Amerika. Cetakan II. Bandung: PT Remaja Rosdakarya.

Pabottinggi, Mochtar.19996. "Bahasa, Kramanisasi, dan Kerakyatan”. Hal. 161. Dalam Yudi Latif dan Idi Subandi Ibrahim (Ed). Bahasa dan Kekuasaan: Politik Wacana di Panggung Orde Baru. Bandung: Mizan.

Polak, Mayor. 1979. Sosiologi suatu Buku Pengantar Ringkas.Jakarta: PT Ichtiar Baru. 